\title{
The Influence of YouTube Advertising on the Attitude towards Fruits and Vegetable Consumption among University Students in Malaysia
}

\author{
NUR SHAHAFIQAH NADIAH JAFFERY \\ SHARIFAH NURAFIZAH SYED ANNUAR \\ JOSEPH ALAGIARAJ THAMBU RAJ \\ Universiti Teknologi MARA, Sabah
}

\begin{abstract}
In 2005 with an emphasis on user-generated content, YouTube has become the predominant stage for online video around the world. Nowadays, YouTube has become increasingly attractive to advertisers, not only in conventional commercials but also in terms of promoting health marketing campaigns. This paper aims to investigate the influence that YouTube advertising has on attitudes towards fruits and vegetable consumption among university students, specifically in Malaysia. For this paper, Tripartite Attitude Model is employed as a foundation model to develop the conceptual framework. Perceived credibility, perceived usefulness, perceived video characteristics, number of likes, views, comments and replies are used as independent variables while attitudes towards fruits and vegetable consumption are treated as a dependent variable. A total of 280 offline questionnaires were distributed in eight local universities in Malaysia. The findings demonstrate that perceived usefulness and number of likes, views, comments and replies are the strongest positive drivers of attitudes towards fruits and vegetable consumption among university students in Malaysia. This paper provides novelty as it contributes to the marketing literature particularly in health marketing and social media studies. In addition, relevant local authorities and health marketers can also benefit from the findings in designing their future health communication campaign.
\end{abstract}

Keywords: YouTube advertising, fruit and vegetable consumption, attitude, tripartite attitude model, health marketing.

\section{INTRODUCTION}

The college years are a time of huge change in the ways of life of undergraduate students (Ha \& Caine-Bish, 2009). With sound examples during college life it might evade interminable infections, for example, ischemic coronary ailment, esophageal dangerous development, gastric malady and lung illness (Lock, Pomerleau, Causer, Altmann \& McKee, 2005). Additionally, a lacking eating routine during college could bring about troublesome physiological outcomes that could prompt eating routine related to chronic diseases (Winkleby \& Cubbin, 2004). The solid eating routine examples of undergraduate students ought to be a worry as demonstrated by a health expert. It is well unsurprising that undergraduate students have unfortunate dietary patterns i.e skipping suppers (Huang, Song, Schemmel \& Hoerr, 1994) and eating snacks nourishment (El Ansari, Stock \& Mikolajczyk, 2012; Porto-Arias, Lorenzo, Lamas, Regal, CardelleCobas \& Cepeda, 2017). Moreover, dietary admissions of undergraduate students give off an impression of being high in fat, immersed fat, cholesterol and sodium (Porto et al., 2017), though they are low in fibre i.e nutrients A, C, and E, for example, folate, iron and calcium (Chourdakis, Tzellos, Papazisi, Toulis \& Kouvelas, 2010). An extensive collection of research uncovers that an eating routine high in fruits and vegetables is related to a diminished danger of incessant illnesses 
(Lock, Pomerleau, Causer, Altmann \& McKee, 2005). Fruits and vegetable consumption among undergraduate students is somewhere in the range of 2.1 and 5.5 servings (Chung \& Hoerr, 2005; Richards, Kattlemann \& Ren, 2006; Baker, 2013), which higher than the present suggestion serving admission which is 2 times each day (Al Ani, Al Subhi \& Bose, 2016). The World Health Organization (WHO) endorses $400 \mathrm{~g}$ of leafy foods consistently and national admissions are neither close nor over this target. Besides, undergraduate students have less awareness than older consumers about the benefits of fruits and vegetable consumption and the impacts of poor dietary practices (Chung, Hoerr, Levine \& Coleman, 2006).

Although various education programs promoting fruits and vegetables consumption utilization moderately hardly any endeavours have focused on undergraduate students (Richards, Kattlemann \& Ren, 2006). Kempen Suku-Suku Separuh in Malaysia has been propelled by the Ministry of Health Malaysia to teach the general population to consume fruits and vegetables to diminish their calorie and fat admission. The campaign was acquainted in 2017 with points with decrease the number of obese people especially among youngsters in Malaysia. The Economic Intelligence Unit's in its report on handling obesity in Asean uncovered that Malaysia has the most elevated corpulence predominance in South East Asia (Farezza, 2017). Besides, in 2012, a school-based sustenance review was directed and found that $93.7 \%$ of youngsters matured 13-17 years of age do not follow the prescribed vegetable serving. Unhealthy food intakes do not only lead to obesity problems yet, in addition, can bring about ceaseless infections, for example, heart issues, hypertension and so forth.

A standout among most standard video-sharing goals is YouTube, which was built up in 2005. YouTube has accomplished mind-blowing development in the number of clients and recordings, and Time magazine has declared it as the making of 2006 (Jarrett, 2008). YouTube promoting has been utilized immensely in profits settings (Viswanath, Ramanadhan \& Kontoz, 2007; Waters \& Jones, 2011) and has been expressed to be viable in empowering buy goal (Viswanath, Ramanadhan \& Kontoz, 2007; Morrison, Cheong, \& McMillan, 2013; Paek, Hove \& Jeon, 2013). With regards to fruits and vegetable consumption, previous studies are dominated in profit settings to quantify the adequacy of YouTube promoting however ailing with regards to fruits and vegetable consumption (Antony \& Thomas, 2010; Tang, Gu \& Whinston, 2012a; Carryer \& Nandamuri, 2014; Burgess \& Green, 2018).

YouTube advertising has been used tremendously in profit settings (Viswanath, Ramanadhan \& Kontoz, 2007; Waters \& Jones, 2011) and has been induced to be effective in encouraging purchase intention (Morrison, Cheong, \& McMillan, 2013; Paek, Hove \& Jeon, 2013). In the context fruits and vegetable consumption, previous studies are dominated in profit setting to measure the effectiveness of YouTube advertising (Anhony \& Thomas, 2010; Tang, Gu \& Whinston, 2012b; Carryer \& Nandamuri, 2014; Burgess \& Green, 2018). For that reason, this study hopes to identify the attributes of YouTube advertising that could attract consumers' attention and change their attitude to consider their health and thus consume fruits and vegetables.

Although the advantages of expending fruits and vegetables are broadly known, undergraduate students face issues to keep up a healthy lifestyle when living ceaselessly from home. The Malaysian government has used numerous apparatuses to elevate smart dieting and to promote healthy eating and encourage consumption of fruits and vegetables. The instruments 
are roadshows, publications, talks and internet-based life stages like YouTube. In literature, the vast majority of the studies have explored the job of YouTube promoting in the profit's settings, and lack of discussion in the health context particularly in fruits and vegetable consumption. Consequently, the purpose of this study is to investigate the components that could impact the consumption of fruits and vegetables among university students.

\section{LITERATURE REVIEW}

\section{Theoretical Framework}

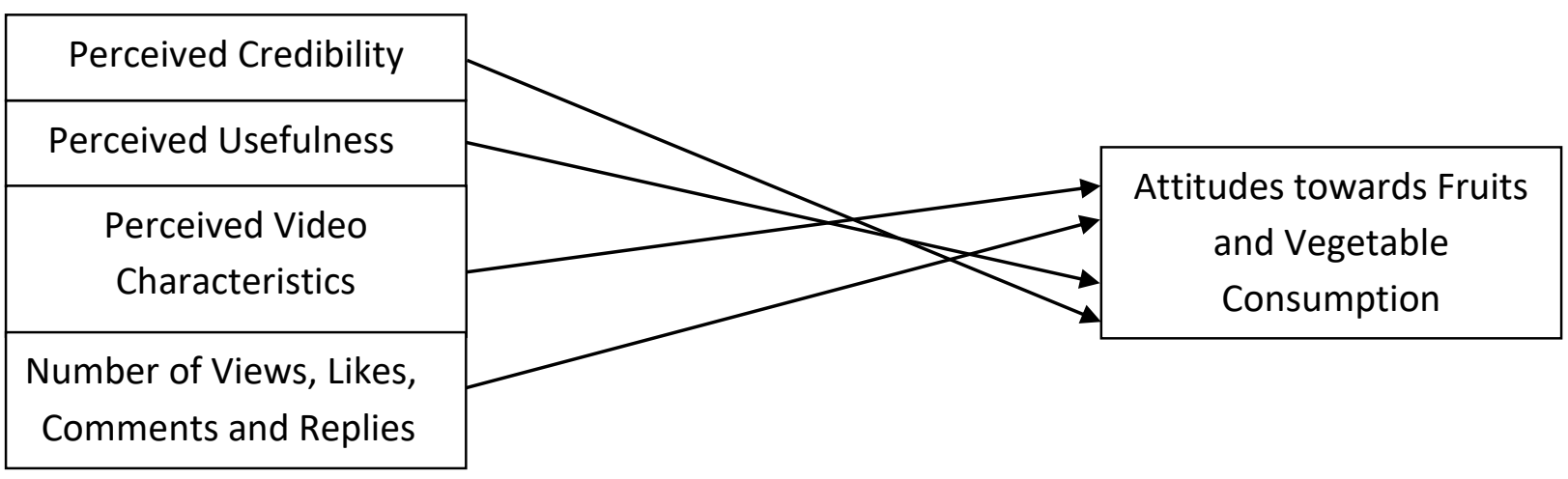

Figure 1: Purposed Framework

YouTube is a video-sharing Web webpage made in February 2005 and is positioned third among the most-visited Web locales on the Internet over the globe. The across the board utilization of cell phones, which oftentimes hold onto YouTube as one of their applications, has made its utilization considerably increasingly normal (Pant, Deshmukh, Murugiah, Kumar, Sachdeva \& Mehta, 2012). YouTube is a rich archive of data and experiences concerning and utilization. Twenty and two nations and more, some phone organizations, for example, iPhone and blackberry were offered a confined form by YouTube, which made it workable for consumers to see YouTube recordings on their handheld (Bradshaw \& Garrahan, 2008). This broad utilization of this stage has made an effect on transit sponsors plan their promotion system (Nielsen, 2012). Also, YouTube runs its accomplice program, which web video makers make a unique new substance for the site to pick up advantage from sharing the income of YouTube 'promotions. Until now, more than 30,000 accomplices from 27 nations have participated in the accomplice program (Kotler \& Armstrong, 2013).

Essentially, there are two sorts of commercial on YouTube video. In-stream video advertising and in-video promoting are two various sorts of ads through YouTube. In-stream promotions let viewers decide to watch brand' promotions, or skip it in the wake of playing for at least $5 \mathrm{~s}$. Standard In-Stream Ads can be a limit of $15 \mathrm{~s}$. In-video promotions are the advertisements that normally show up on the lower segment of society's video. These promotions normally show up for the $15 \mathrm{~s}$ mark that the viewer whenever wanted can close or limit them (Adage, 2014; Pikas \& Sorrentino, 2014). Although TV remains the essential type of media and holds a moderately steady effect, web-based life channels, for example, YouTube 
keeps on developing, which is encountering an extensive increasing speed in the improvement of promoting ventures (Adage, 2014; Bellman, Schweda, \& Varan, 2009; Clancey, 1994). Along these lines, one emerged question is whether publicists who are encountering the impacts of promoting substitution among YouTube and different types of media could work this new condition to get the best return of speculation with the assistance of YouTube promoting.

Regardless of the basic need to investigate all parts of YouTube as a new promoting stage, information is absence concerning the promoting plan for society. In this manner, the present research endeavours to fill gaps by examining if and how YouTube advertisement influences consumers' goals to buy. To the best of our insight, limited studies have tried the relationship between YouTube advertisement factors on the benefit of consuming fruits and vegetables in Malaysia among university students.

Early conceptualization of the YouTube advertisement is proposed by Yüksel (2016) which included perceived credibility, perceived usefulness, perceived video characteristics, number of views, likes, comments and replies. However, previous studies by researchers, for example, SeeTo (2014), Gunawan and Huarng (2015), Lee and Watkins (2016) with Deghani, Niaki, Ramezami and Sali (2016) have for the most investigated about the study of YouTube towards purchase intention in profit settings. Despite that, the scales used to gauge credibility in the investigations are reliability and validity and hence, making it impossible to compare findings and generate a conclusion.

\section{a. Perceived Credibility}

In general, the credibility of a source can be characterized as the positive feature of the source that affects the beneficiary to recognize the message (Ohanian, 1990). Credibility is a thought which is described by the judgment of the reader (Freeman \& Spyridakis, 2004) and studies in the literature show that rather than a source, stage or message feature, it depends upon the recipient's observations (Akhondan, Johnson-Carroll \& Rabolt, 2008). Perceived credibility is the trust estimation that impacts the apportionment of a message positively or negatively and it can change the customer's attitude (Bouhlel et al., 2010). The reception of information according to perceived credibility is an expansion material to an online environment (Cheung, Sia \& Kuan, 2009).

Greer (2003) found that the perceived credibility of online information affects people's attitudes towards the story they read. In the context of health communication, perceived website credibility influences people's valuation of online health information (Wang, Walther, Pingree \& Hawkins, 2008). In advertising, the existing research study has excavated that perceived credibility of advertising endorsers is positively related to consumer attitudes towards the advertisement (Goldsmith, Lafferty \& Newell, 2000). Rifon, Choi, Trimble, and Li (2004) found a positive relationship between the perceived credibility of website sponsors and the attitude towards the sponsor. Long and Chiagouris (2006) uncovered that the perceived credibility of a nonprofit organisation's website influenced site visitors' attitudes towards the website. 
Empirical studies have studied how perceived information credibility or source credibility affects consumers' attitudes, purchase intentions, and actual purchase behaviour's in the perspectives of traditional media platforms (DeShields, Kara \& Kaynak, 1996; Sallam \& Wahid, 2012; Teng, Khong, Goh \& Chong, 2014). However, due to YouTube influencers' continuous presence on this popular social platform, and the active role of consumers in sharing the consumption of content on YouTube, the video is likely to be different from the traditional advertising (Xiao, Wang \& Chan-Olmsted, 2018). To discover how perceived information credibility impacts consumer attitudes towards the video and the benefits from eating fruits and vegetables mentioned in the video, the study should be started with the analysis of backgrounds that are related to perceived information credibility.

\section{b. Perceived Usefulness}

A previous study by Davis (1989) mentioned perceived usefulness as "how much an individual can trust that using a system would upgrade his or her activity execution", and it is related to the wants that an individual intends to get finally (McKnight \& Kacmar, 2007). Pavlou and Fygenson (2006) characterized perceived usefulness from destinations as the conviction that information will overhaul efficiency in procuring thing information. An examination related to web journals (Bouhlel, Mzoughi, Ghachem \& Negra, 2010) reveals that perceived usefulness is related to the benefits of web sites and these points of interest can prevent waste of time and accessing extra information and different perspectives about products.

Videos have also become an essential part of education, with the most visible example being the constant growth of participation in enormous open online courses (MOOCs) that are mostly video-based. For educational videos to be effective among students, some researchers have suggested that they should be considered while paying attention to aspects beyond the content-level, for example, length (brevity), way of speaking (passion) or graphics (comic-style animation) (Almeida, Jameson, Riesen \& McDonnell, 2016; Brame, 2016). Remarkably, these commendations highlight the need to study how educational videos are assessed for credibility, especially the role that their no content-related characteristics play in credibility assessment. Previous studies have shown that YouTube harbours science videos with high educational value. According to the studies, such videos with high educational value do manage to engage users, yet they do not essentially participate users more than videos with low educational value (Desai, Shariff, Dhingra, Minhas, Eure \& Kats, 2013; Hayat and Hershkovitz, 2018). Also, the technical quality was shown to be positively associated with perceived credibility of online news videos and advertising videos (Chen, Chen, Chang \& Abedin, 2017; Hautz, Füller, Hutter \& Thürridl, 2014). However, studies of the role of such minor prompts in credibility assessment of science news videos are occasional.

According to the Technology Acceptance Model (TAM), perceived usefulness influences attitudes (Mir \& Ur Rehman, 2013). Bouhlel et al. (2010) support this hypothesis for websites by indicating attitudes affects perceived usefulness. Hsu, Wang and Lin (2013) also found that the usefulness of blog recommendations legitimately influences attitudes and indirect purchase intention. In an examination of web advantage acceptance, Yang et al. (2010) exhibited that perceived usefulness has both direct usefulness on usage intention and indirect effect on the 
The Influence of YouTube Advertising on the Attitude towards Fruits and Vegetables Consumption among University Students in Malaysia

Nur Shahafiqah Nadiah Jaffery, Sharifah Nurafizah Syed Annuar \& Joseph Alagiaraj Thambu Raj

purchase intention. In the present study, perceived usefulness of the information in the videos is recognized as the impression of customers viewing YouTube videos will influence consumption.

\section{c. Perceived Video Characteristics}

YouTube, which was created in 2005 , allows users to upload and share video content. Its success was immediate, resulting in spectacular growth ever since. For instance, the number of videos viewed per day has increased from around 200 Million in 2007 to more than 4 Billion in 2012 (Kontothannsis, 2012). Since YouTube was acquired in late 2007 by Google, its infrastructure has been in constant evolution and the delivery architecture that initially used third party content distribution network services is now fully operated and managed by Google. Not much about YouTube has been disclosed by Google itself (Kontothannsis, 2012; Brodersen, Scellato \& Wattenhoefer, 2012; Ghobadi, Cheng, Jain \& Matthis, 2012). An average of one hour of the video was uploaded every second, which is a three-fold increase as compared to 2009. The number of videos downloaded per day has been evaluated in 2011 to be between 1.7 and 4.6 Billion representing a $50 \%$ increase over the previous year, which results in tens of PetaBytes of traffic per day (Hoßfeld, Schatz, Biersack \& Plissonneau, 2013).

Express features of YouTube videos may affect purchase intention. In any case, the nature of the video is a factor that affects purchasing decisions (Woods, Satgunam, Bronstad \& Peli, 2010) and great videos increment user commitment (Dobrian, Awan, Joseph, Ganjam, Zhan, Sekar \& Zhang, 2013). Besides, the acknowledgement about the length of the video may get one of the impact adequacies on YouTube advertising factors. The outcome of an investigation on by and large shared Top 50 YouTube recordings reveal that the typical length for advertising videos is 3-3.5 minutes; in any case, the longing to share relies more upon the nature of emotions that the video rouses from the watchers (Jarboe, 2012). In any way, the specific length of the video yet rather its impression may be a factor that impacts attitudes and purchase intention. Besides, the arrangement and introduction of the substance are powerful to influential to consumer purchase intention. This can impact the dimension of information the consumers acquire and lead to attitude improvement.

\section{d. Number of Views, Likes, Comments and Replies}

Furthermore, the number of views, likes, comments and replies are consumers' perceptions about content and can impact different consumers. Comments on the online substance about an item might be seen as an indication of product quality and can influence purchase intention (Lee \& Shin, 2009). For purchasers who find online information credible, the number of comments expands the validity of that information (O'Reilly \& Marx, 2011). The comment sections additional YouTube videos provide viewers of the video a virtual venue to exchange ideas. These user comments exhibit the social function of YouTube. Through the exchange of ideas in the comment section, viewers of the video and the host of the channel interact with each other. Such interactions are very likely to shape people's beliefs. Empirical studies suggest that peer or social influence, such as a large number of people who prompt a similar opinion about something online, strongly impacts the formation of one's beliefs (Fu, 2012; Sundar, 2008; Xu, Schmierbach, Bellur, Ash, Oeldorf-Hirsch \& Kegerise, 2012). Individuals are more likely to believe a message to be true when most people consider the message is true because it is a simple, empirical 
information cue that helps them process the information (Chaiken, 1987). YouTube users who look for user-created content additionally consider the comments and the number of comments to increase the credibility and usefulness of the videos (Mir \& Rehman, 2013). Ratings are also significant for assessing the credibility of online substance (Hocevar, Flanagin \& Metzher, 2011). While, the number of likes affects the credibility of contents in forums (O'Reilly \& Marx, 2011); this impact likewise applies to YouTube videos and the number of likes increments the notoriety of videos prompting expanded credibility and usefulness (Mir \& Rehman, 2013). Initially, as proposed by Mir and Rehman (2013) the number of likes on the substance on YouTube is significant towards the impression of credibility and usefulness. In this way, it is intriguing to recommend that the number of replies to the comments by the video owner may also affect the perception of credibility and usefulness of the information given in the video.

Ducoffe (1996) showed that entertainment, informativeness and irritation influenced attitudes toward Web advertisements. The content (informativeness) and form (entertainment) of ads are important predictors of their value and are crucial to the effectiveness of Web advertising, while irritation has negative impacts on viewer attitudes. Although some researchers have assumed that attitudes are an important construct of internet advertising (Ducoffe, 1996), Schlosser et al. (1999) thought it additionally conceivable that the unique characteristics of the internet, when used primarily as an information-providing medium, might cause the underlying structure of attitudes toward internet advertising to differ. Their study viewed internet advertisements as increasingly instructive and reliable. They found not only that the traditional assessments of advertising effectiveness (i.e. considering the information and entertainment value) would apply to advertise on the Web, but also that the advertisement's utility for making behavioural (purchasing) decisions would influence viewer attitudes toward internet advertising.

Brackett and Carr (2001) thought that attitudes toward online advertisements are the aggregation of weighted evaluations of perceived attributes and consequences of products, and they developed an integrated Web advertising attitude model modified from several earlier studies.

\section{e. Tripartite Attitude Model}

Consumers' perspectives establish a significant reason for planning and assessing marketing strategy. Mentality measures are utilized to assess new items, survey promoting adequacy, and decide constituents' opinion toward political and social issues. These practices are predicated on the suspicion that people's mentalities anticipate their conduct, and information on customers' attitudinal impressions is essential to the improvement of powerful interest incitement techniques.

Spooncer (1992) model of attitude otherwise called Tripartite Model. This model comprises of three parts of disposition: Feelings, Beliefs and Behavior. The first segment incorporates a person's feeling which speaks to verbal proclamations of feeling, whereas the second segment incorporates a person's subjective reaction which speaks to verbal explanations of conviction lastly the third part incorporates a person's clear activity which speaks to verbal articulations about planned conduct against environmental stimuli. 


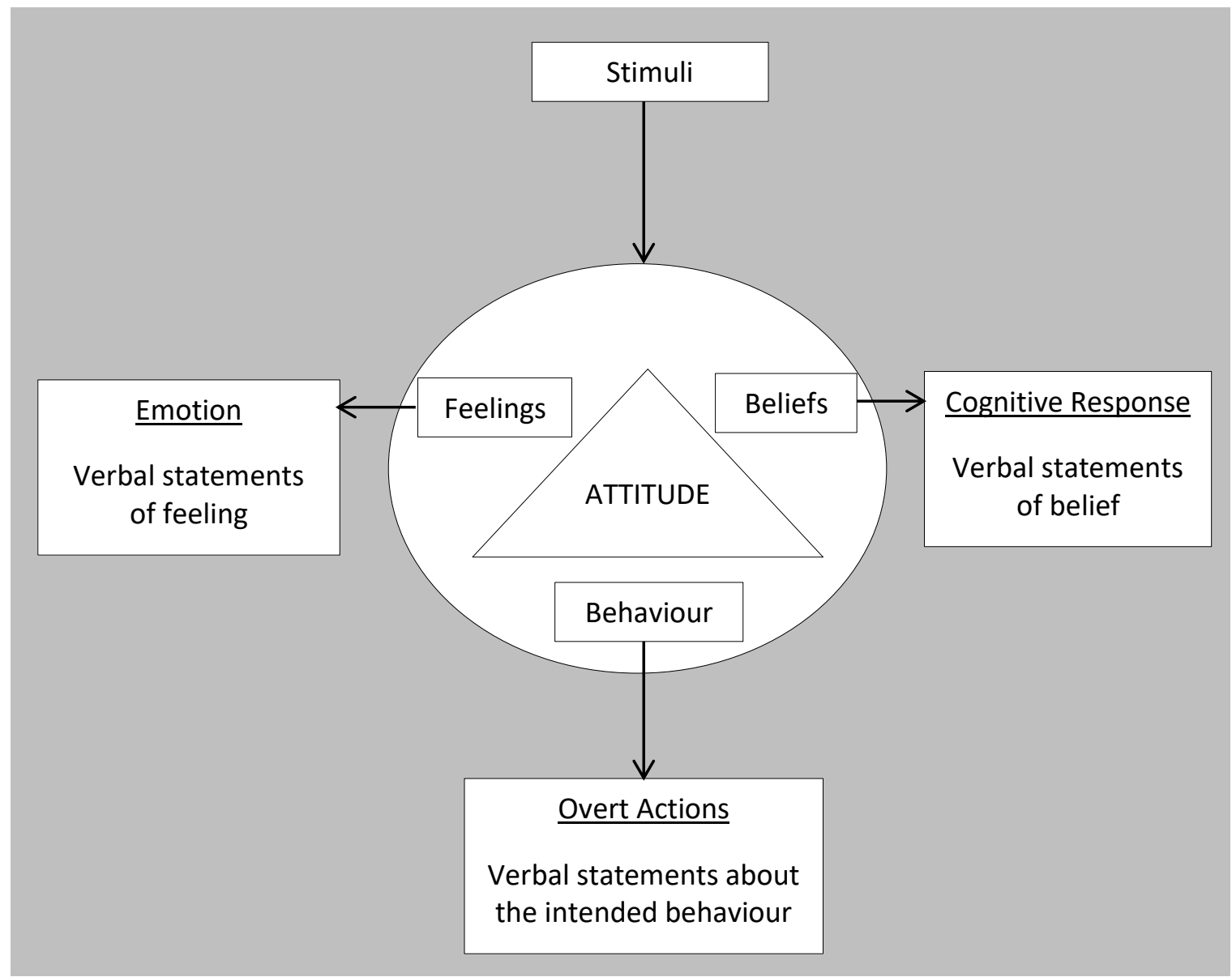

Figure 2: Tripartite Attitude Model

The above-mentioned dimensions have so far, never been tested simultaneously in a study and the ability to know which dimensions are significant is unknown. Hence, there is a knowledge gap necessary to address. Besides, the act of consuming fruits and vegetables are the basic needs; therefore, it will be noteworthy to know that the YouTube Advertising has a significant effect towards attitudinal change in the context of consuming fruits and vegetables. Based on the discussion above, the hypotheses and research framework for this study is purposed as follows:

$\mathbf{H}_{1}$ : There is a positive relationship between perceived credibility and attitude towards fruits and vegetable consumption.

$\mathbf{H}_{\mathbf{2}}$ : There is a positive relationship between perceived usefulness and attitude towards fruits and vegetable consumption.

$\mathbf{H}_{3}$ : There is a positive relationship between perceived video of characteristics and attitude towards fruits and vegetable consumption.

$\mathbf{H}_{4}$ : There is a positive relationship between the number of views, likes, comments and replies and attitude towards fruits and vegetable consumption. 


\section{METHODOLOGY}

This paper centres around undergraduate university students in Malaysia as the sample of the study. Data were collected in eight public universities in Malaysia. Questionnaires were prepared and used in this study to accumulate information on the background of respondents, YouTube advertising and attitude towards fruits and vegetable consumption among university students in Malaysia. The sample size was determined using the G-power software. There were four predictors tested in this study, hence, at effect size 0.02 (small), and the power required at 0.95, the required sample size was equal to 128 . However, to ensure that the optimum level of the number of respondents was achieved, the questionnaires in this study were distributed to 280 respondents.

The YouTube advertising measurements consist of perceived credibility, perceived usefulness, perceived video characteristics and the number of views, likes, comments and replies (Yüksel, 2016). In addition, items Yüksel (2016) are borrowed to measure attitude towards fruits and vegetable consumption. All items are constructed using a five-point Likert Scale ranging from "strongly disagree" (1) to "strongly agree" (5).

Table 1: Demographic Profile

\begin{tabular}{|c|c|c|c|c|}
\hline $\begin{array}{c}\text { Demographic } \\
\text { Variable }\end{array}$ & Categories & Frequency & Percent & Cumulative Per cent \\
\hline \multirow[t]{3}{*}{ Gender } & Male & 126 & 45.0 & 45.0 \\
\hline & Female & 154 & 55.0 & 100.0 \\
\hline & Total & 280 & 100.0 & \\
\hline \multirow[t]{11}{*}{ Age } & 18 years old & 12 & 4.3 & 4.3 \\
\hline & 19 years old & 48 & 17.1 & 21.4 \\
\hline & 20 years old & 61 & 21.8 & 43.2 \\
\hline & 21 years old & 53 & 18.9 & 62.1 \\
\hline & 22 years old & 32 & 11.4 & 73.6 \\
\hline & 23 years old & 27 & 9.6 & 83.2 \\
\hline & 24 years old & 23 & 8.2 & 91.4 \\
\hline & 25 years old & 19 & 6.8 & 98.2 \\
\hline & 26 years old & 4 & 1.4 & 99.6 \\
\hline & 27 years old & 1 & .4 & 100.0 \\
\hline & Total & 280 & 100.0 & \\
\hline \multirow[t]{6}{*}{ Race } & Malay & 168 & 60.0 & 60.0 \\
\hline & Chinese & 52 & 18.6 & 78.6 \\
\hline & India & 27 & 9.6 & 88.2 \\
\hline & Bumiputera Sabah & 21 & 7.5 & 95.7 \\
\hline & Bumiputera Sarawak & 12 & 4.3 & 100.0 \\
\hline & Total & 280 & 100.0 & \\
\hline \multirow[t]{9}{*}{ Hometown } & Sabah & 33 & 11.8 & 11.8 \\
\hline & Sarawak & 16 & 5.7 & 17.5 \\
\hline & Pulau Pinang & 17 & 6.1 & 23.6 \\
\hline & Selangor & 44 & 15.7 & 39.3 \\
\hline & Kedah & 25 & 8.9 & 48.2 \\
\hline & Kelantan & 32 & 11.4 & 59.6 \\
\hline & Perlis & 8 & 2.9 & 62.5 \\
\hline & Perak & 10 & 3.6 & 66.1 \\
\hline & Negeri Sembilan & 8 & 2.9 & 68.9 \\
\hline
\end{tabular}


The Influence of YouTube Advertising on the Attitude towards Fruits and Vegetables Consumption among University Students in Malaysia

Nur Shahafiqah Nadiah Jaffery, Sharifah Nurafizah Syed Annuar \& Joseph Alagiaraj Thambu Raj

\begin{tabular}{|c|c|c|c|c|}
\hline & Terengganu & 7 & 2.5 & 71.4 \\
\hline & Melaka & 8 & 2.9 & 74.3 \\
\hline & Johor & 19 & 6.8 & 81.1 \\
\hline & Pahang & 10 & 3.6 & 84.6 \\
\hline & Labuan & 9 & 3.2 & 87.9 \\
\hline & Putrajaya & 24 & 8.6 & 96.4 \\
\hline & China & 10 & 3.6 & 100.0 \\
\hline & Total & 280 & 100.0 & \\
\hline \multirow[t]{3}{*}{ Marital Status } & Single & 272 & 97.1 & 97.1 \\
\hline & Married & 8 & 2.9 & 100.0 \\
\hline & Total & 280 & 100.0 & \\
\hline \multirow[t]{9}{*}{ Universities } & $\begin{array}{l}\text { Universiti Malaysia } \\
\text { Sabah }\end{array}$ & 35 & 12.5 & 12.5 \\
\hline & $\begin{array}{c}\text { Universiti Kebangsaan } \\
\text { Malaysia }\end{array}$ & 35 & 12.5 & 25.0 \\
\hline & $\begin{array}{l}\text { Universiti Putra } \\
\text { Malaysia }\end{array}$ & 35 & 12.5 & 37.5 \\
\hline & Universiti Malaya & 35 & 12.5 & 50.0 \\
\hline & $\begin{array}{c}\text { Universiti Tun Hussein } \\
\text { Onn Malaysia }\end{array}$ & 35 & 12.5 & 62.5 \\
\hline & $\begin{array}{l}\text { Universiti Sains } \\
\text { Malaysia }\end{array}$ & 35 & 12.5 & 75.0 \\
\hline & $\begin{array}{l}\text { Universiti Malaysia } \\
\text { Kelantan }\end{array}$ & 35 & 12.5 & 87.5 \\
\hline & $\begin{array}{l}\text { Universiti Sultan Zainal } \\
\text { Abidin }\end{array}$ & 35 & 12.5 & 100.0 \\
\hline & Total & 280 & 100.0 & \\
\hline \multirow[t]{3}{*}{ Stream of Study } & Science & 103 & 36.8 & 36.8 \\
\hline & Non-Science & 177 & 63.2 & 100.0 \\
\hline & Total & 280 & 100.0 & \\
\hline
\end{tabular}

Table 2: Internal Consistency Reliability

\begin{tabular}{cccccc}
\hline Construct & Item & $\begin{array}{c}\text { Outer } \\
\text { Loadings }\end{array}$ & $\begin{array}{c}\text { Cronbach's } \\
\text { Alpha }\end{array}$ & $\begin{array}{c}\text { Composite } \\
\text { Reliability }\end{array}$ & $\begin{array}{c}\text { Average Variance } \\
\text { Extracted (AVE) }\end{array}$ \\
\hline Attitude & ATT1 & 0.843 & 0.917 & 0.942 & 0.802 \\
& ATT2 & 0.881 & & & \\
& ATT3 & 0.955 & & & \\
& ATT4 & 0.899 & & 0.919 & \\
$\begin{array}{c}\text { Number of Views, } \\
\text { Likes, Comments } \\
\text { and Replies }\end{array}$ & NVLCR1 & 0.911 & 0.869 & & \\
& & & & & \\
NVLCR2 & 0.954 & & & \\
Perceived & NVLCR3 & 0.798 & & & \\
Credibility & PC1 & 0.839 & 0.838 & & \\
& PC2 & 0.917 & & & \\
& PC3 & 0.844 & & & \\
\hline
\end{tabular}




\begin{tabular}{cccccc}
\hline $\begin{array}{c}\text { Perceived } \\
\text { Usefulness }\end{array}$ & PU1 & 0.771 & 0.895 & 0.92 & 0.658 \\
& PU2 & 0.786 & & & \\
& PU3 & 0.744 & & & \\
& PU4 & 0.734 & & & \\
& PU5 & 0.92 & & & \\
& PU6 & 0.894 & & 0.749 \\
Perceived Video & PVC1 & 0.897 & 0.83 & & \\
& & & & & \\
\hline
\end{tabular}

Table 3: Heterotrait-Monotrait Ratio or Correlations (HTMT) Loadings

\begin{tabular}{cccccc}
\hline & ATT & NVLCR & PC & PU & PVC \\
\hline ATT & & & & & \\
NVLCR & 0.41 & & & \\
PC & 0.573 & 0.403 & & \\
PU & 0.823 & 0.376 & 0.66 & \\
PVC & 0.379 & 0.266 & 0.477 & 0.497 & \\
\hline
\end{tabular}

Table 4: Hypotheses Testing

\begin{tabular}{|c|c|c|c|c|c|c|c|c|}
\hline Hypothesis & Relationship & Std Beta & Std Error & $t$ value & P Values & $5.00 \%$ & $95.00 \%$ & Decision \\
\hline $\mathbf{H}_{1}$ & $P C->$ ATT & 0.076 & 0.052 & 1.482 & 0.069 & -0.003 & 0.159 & $\begin{array}{c}\text { Not } \\
\text { Supported }\end{array}$ \\
\hline $\mathrm{H}_{2}$ & $\mathrm{PU}->\mathrm{ATT}$ & 0.667 & 0.046 & 14.489 & 0 & 0.59 & 0.738 & Supported \\
\hline $\mathrm{H}_{3}$ & PVC -> ATT & -0.015 & 0.048 & 0.309 & 0.379 & -0.094 & 0.067 & $\begin{array}{c}\text { Not } \\
\text { Supported }\end{array}$ \\
\hline $\mathrm{H}_{4}$ & NVLCR $\rightarrow$ ATT & 0.096 & 0.034 & 2.811 & 0.003 & 0.037 & 0.149 & Supported \\
\hline
\end{tabular}

Table 5: The results of R2, F2 and Q2

\begin{tabular}{ccccc}
\hline Hypothesis & Relationship & R2 & F2 & Q2 \\
\hline $\mathbf{H}_{\mathbf{1}}$ & PC - ATT & & 0.009 & \\
$\mathbf{H}_{\mathbf{2}}$ & PU -> ATT & & 0.649 & \\
$\mathbf{H}_{\mathbf{3}}$ & PVC -> ATT & & 0 & \\
$\mathbf{H}_{\mathbf{4}}$ & NVLCR $>$ ATT & 0.597 & 0.006 & 0.444 \\
\hline
\end{tabular}

Responses from 280 respondents were collected and the data were analyzed using IBM SPSS Statistics 24 and Smart PLS 3.0. The total variance for the Harman Single Factor for this study was $25.005 \%$ which indicates that this data is free from common method bias. Table 1 shows the demographic profile of the respondents in this study. In the demographic analysis, most of the respondents were female with $55 \%$ while male respondents made up $45 \%$. The largest group of samples was those age is 20 years old $(21.8 \%)$. The highest marital status of the respondents is single with 272 respondents (97.1\%) while married respondents were $2.9 \%$ only. Most of the 
The Influence of YouTube Advertising on the Attitude towards Fruits and Vegetables Consumption among University Students in Malaysia

Nur Shahafiqah Nadiah Jaffery, Sharifah Nurafizah Syed Annuar \& Joseph Alagiaraj Thambu Raj

respondents were from non-science stream with $36.8 \%$ and followed by the science stream with $63.2 \%$.

The largest group of the sample was the age of 20 years old (21.8\%), followed by 21 years old $(18.9 \%)$ and 19 years old $(17.1 \%), 22$ years old $(11.4 \%), 23$ years old $(9.6 \%), 24$ year olds (8.2\%), 25 years old (6.8\%) and 18 years old (4.3\%). The remaining age group are 26 years old with $1.4 \%$ and 24 years old with $0.4 \%$. There are proportions of $55 \%$ females to $45 \%$ male respondents in this study.

The race background reveals that the respondents predominantly are Malay $(60.0 \%)$ and Chinese (18.6\%). The list is followed by India, 9.6\%, Indian with 5.8\% and Bumiputera Sabah with $37.5 \%$. The other race backgrounds are Bumiputera Sarawak with $4.3 \%$.

Most of the respondents come from Selangor (15.7\%), Sabah (11.8\%) and Kelantan (11.4\%). The other respondents are from Kedah (8.9\%), Putrajaya (8.6\%), Johor (6.8\%), Pulau Pinang (6.1\%) and Sarawak (5.7\%). Perak, Pahang and China with 3.6\% respectively and Perlis, Negeri Sembilan and Melaka with $2.9 \%$ respectively. The remainder is from Labuan with $3.2 \%$ and Terengganu $2.5 \%$.

Educational background of the respondents showed that most of the respondents are undergraduates of Faculty of Law with 18.6\%, Faculty of Business, Economics and Accountancy with $12.5 \%$, School of Educational Studies 7.5\%, followed by Faculty of Education and Faculty of Islamic Contemporary Studies with 6.4\%. Faculty of Creative Technology and Heritage and Faculty of Arts and Social Sciences with 6.1\%. Others studying in School of Management (4.6\%), Faculty of Engineering and Faculty of Civil and Environmental Engineering respectively (4.3\%), Faculty of Applied Science (3.9\%), Faculty of Design and Agriculture, School of Agriculture, Faculty of Entrepreneurship and Business respectively (3.6\%), and Faculty of Computer Science and Technology, Faculty of Agriculture, Faculty of Agro-Based Industry with $2.9 \%$ respectively.

\section{FINDINGS}

In this study, demographic data were analyzed using IBM SPSS 24 while the measurement path modelling analysis was performed using Smart PLS 3.0. In analyzing the research model, the Partial Least Squares (PLS) analysis was utilized using the Smart PLS 3.0 software. As to examine the outer loadings thresholds, Average Variance Extracted (AVE) and Composite Reliability (CR) were performed to determine the validity of the measurement model. According to Hair Jr., Black, Babin and Anderson (2017), the outer loading should be $>0.70$ threshold value, Composite Reliability (CR) $>0.70$ and Average Variance Extracted (AVE) $>0.50$. However, outer loading values equal to and greater than 0.4 are still acceptable, given the cumulativeness of loadings result in high loading scores which lead to Average Variance Extracted (AVE) scores greater than 0.5 (Hulland, 1999). Based on Table 2, the Average Variance Extracted (AVE) values were all greater than 0.5 and the Composite Reliability (CR) scores in the result were greater than 0.70 . Loadings which do not meet the minimum threshold scores were deleted. In analyzing the discriminant validity, this paper followed the suggestion by Henseler, Ringle and Sarstedt (2015) to assess discriminant validity using Heterotrait-Monotrait ratio of correlations (HTMT). Heterotrait-Monotrait ratio of correlations (HTMT) value is greater than Heterotrait-Monotrait ratio of correlations (HTMT) 0.85 value of 0.85 (Kline, 2011) or HTMT.90 value of 0.90 (Gold, Malhotra \& Segars, 2001) and this means that the discriminant validity problem is not a concern. 
According to Hair Jr. et al. (2014), the hypotheses developed for this study was tested using a bootstrapping procedure. The R2 for this study is 0.597 which is acceptable according to Cohen (1988). Based on the result in Table 4, the assessment of the path coefficient shows that only two relationships are found to have t-value greater than 1.645 thus significant at 0.05 . The predictors are perceived usefulness (14.489) and the number of views, likes, comments and replies (2.811). The independent variable (perceived credibility, perceived usefulness, perceived video characteristics and the number of views, likes, comments and replies) in Table 4, explains 59.7\% variances of the dependent variable. $\mathrm{H} 2$ and $\mathrm{H} 4$ in this study are supported. The effect sizes (f2) for the two relationships achieved either from small to medium effect size as suggested by Cohen (1988). The Q2 value is greater than 0 which indicates the model has a predictive relevance (Hair Jr. et al., 2014; Fornell \& Cha, 1994).

\section{DISCUSSION AND CONCLUSION}

This study has shown that the perceived usefulness has a positive relationship towards attitude to consume fruits and vegetables. However, most of the studies have found perceived usefulness was significantly having a positive relationship in non-profit settings, which is purchase intention (Bouhlel, 2010; Hsu et al., 2013; Yang et al., 2010). This result consumer gets higher interest to consume or purchase a product or services if the content of information given in YouTube advertising is useful and reduce the risk in making decisions. It was also shown that number of views, likes and comments have a positive effect on perceived credibility (Flanagin et al., 2011; Mir \& Rehman, 2013; O'Reilly \& Marx, 2011) which also significantly positive in this study. Nevertheless, the number of views, likes, comments and replies has no effect on the first reviewer to the YouTube advertisement because the interactions between other users can influence others consumer awareness towards the video advertisement.

However, perceived credibility was found not significant in this study. According to Pant et al. (2012), defining a single quality standard for assessing the credibility of such a disparate collection of resources is indeed challenging. Further work needs to be done to establish to achieve the user's interest in watching a video advertisement. On the other hand, perceived video characteristics in a video were also found not significant in this study. As a YouTube user, individuals are tending to get influenced by surroundings with trends or popularity video that going viral whether the content of the video is not useful. If the advertisement of the video is trending, therefore, the advertisements will gain more viewers and it can help to raise awareness among consumers towards the importance of fruits and vegetables.

From the review, it is concluded that YouTube advertising is an effective and efficient platform to raise awareness of fruits and vegetable consumption and to increase the awareness of consumers to eat fruits and vegetables. Targeting university; especially university students are relevant as these groups have strong influences within their social network and thus, can encourage others to have a healthy diet (Dehghani, Niaki, Ramezani \& Sali, 2016; Porto et al., 2017). Nevertheless, before creating a video advertisement of fruits and vegetables, the Ministry of Health or the public must conduct situation analysis to identify the right method to run the campaign. To integrate fruits and vegetable awareness campaign in universities require thorough planning and budget. Because of this, there is a call for future research to measure the effectiveness of YouTube advertising in local universities and to determine which methods are 
the most appropriate to be executed in the Malaysian's context. Hence, this review proposes YouTube advertising as a hopeful intervention method to raise the number of fruits and vegetable consumption and to get people to stay healthy with the proposed research framework, the researchers intend to test the hypotheses in their future research.

\section{BIODATA}

Nur Shahafiqah Nadiah Jaffery is a Master of Science in Business and Management, major in Marketing, from Universiti Teknologi MARA (UiTM), Sabah, Malaysia, is from Sandakan, Sabah. Miss Nadiah's undergraduate paper focused on service quality of outpatients towards private hospitals in Kota Kinabalu, Sabah, and currently interested in continuing to study the effectiveness of YouTube advertising towards intention to consume fruits and vegetables among university students. Email: nadia_eppy@ymail.com

Dr. Sharifah Nurafizah Syed Annuar is currently a Senior Lecturer and Deputy Rector of Research Industrial Linkages, Community, Alumni \& Network Division, Universiti Teknologi MARA (UiTM), Sabah Branch, Malaysia. Her research interests include consumer behaviour, marketing communication, marketing management, health and social marketing, entrepreneurship and management. Email: shari399@uitm.edu.my

Mr. Joseph Alagiaraj Thamburaj is an English Language lecturer at the Universiti Teknologi MARA (UiTM), Sabah, Malaysia. Mr. Joseph has an interest in e-learning, particularly in the effective teaching of young adult literature in the classroom. Email: joe1@uitm.edu.my 


\section{REFERENCES}

Amre, D. K., D'souza, S., Morgan, K., Seidman, G., Lambrette, P., Grimard, G., \& Chotard, V. (2007). Imbalances in dietary consumption of fatty acids, vegetables, and fruits are associated with risk for Crohn's disease in children. The American Journal of Gastroenterology, 102(9), 2016.

Adage. (2014). YouTube effort boosts awareness, but what about ad sales?. Retrieved on August 01, 2014, from http://adage.com/article/digital/results-youtube-s-ads-vice-newsmakerstudios/294421/

Akhondan, H., Johnson-Carroll, K., \& Rabolt, N. (2015). Health consciousness and organic food consumption. Journal of Family \& Consumer Sciences, 107(3), 27-32.

Al Ani, M. F., Al Subhi, L. K., \& Bose, S. (2016). Consumption of fruits and vegetables among adolescents: a multi-national comparison of eleven countries in the Eastern Mediterranean Region. British Journal of Nutrition, 116(10), 1799-1806.

Almeida, C. M., Jameson, J. M., Riesen, T., \& McDonnell, J. (2016). Urban and rural preservice special education teachers' computer use and perceptions of self-efficacy. Rural Special Education Quarterly, 35(3), 12-19.

Antony, M. G., \& Thomas, R. (2010). This is citizen journalism at its finest: YouTube and the public sphere in the Oscar Grant shooting incident. New Media \& Society, 12(8), 1280-1296.

Baker, S. D. (2013). Guidelines for Promoting My Plate and its Website among College Students. University of Delaware.

Bellman, S., Schweda, A., \& Varan, D. (2009). A comparison of three interactive television ad formats. Journal of Interactive Advertising, 10(1), 14-34.

Brunt, A. R., \& Rhee, Y. S. (2008). Obesity and lifestyle in US college students related to living arrangemeents. Appetite, 51(3), 615-621.

Bouhlel, O., Mzoughi, N., Ghachem, M. S., \& Negra, A. (2010). Online purchase intention: Understanding the blogosphere effect. International Journal of E-business Management, 4(2), 37.

Bradshaw, T., \& Garrahan, M. (2008). Rival forecast to catch YouTube. Financial Times. Retrieved from http://us.ft.com/ftgateway/superpage.ft

Brackett, L. K., \& Carr, B. N. (2001). Cyberspace advertising vs. other media: Consumer vs. mature student attitudes. Journal of Advertising Research, 41(5), 23-32.

Brame, C. J. (2016). Effective educational videos: Principles and guidelines for maximizing student learning from video content. CBE-Life Sciences Education, 15(4), es6.

Brodersen, A., Scellato, S., \& Wattenhoefer, M. (2012, April). YouTube around the world: Geographic popularity of videos. Presented at Proc. of 21th International World Wide Web Conference (WWW 2012), Lyon, France.

Burgess, J., \& Green, J. (2018). YouTube: Online video and participatory culture. West Sussex, US: John Wiley \& Sons.

Carryer, N., \& Nandamuri, T. (2014). Online videos in the non-profit sector: Using YouTube to Study Marketing Communications.

Chaiken, S. (1980). Heuristic versus systematic information processing and the use of source versus message cues in persuasion. Journal of Personality and Social Psychology, 39(5), 752-766. 
Chaiken, S. (1987). The heuristic model of persuasion. In M. P. Zanna, J. M. Olson, \& C. P. Herman (Eds.), Ontario symposium on personality and social psychology. Social influence: The Ontario symposium (Vol. 5, pp. 3-39). Hillsdale, NJ, US: Lawrence Erlbaum Associates, Inc.

Cheung, C. M. Y., Sia, C. L., \& Kuan, K. K. (2012). Is this review believable? A study of factors affecting the credibility of online consumer reviews from an ELM perspective. Journal of the Association for Information Systems, 13(8), 618.

Chen, G. M., Chen, P. S., Chang, C. W., \& Abedin, Z. (2017) News video quality affects online sites' credibility. Newspaper Research Journal, 38(1), 19-31.

Choi, S. M., \& Rifon, N. J. (2002). Antecedents and consequences of web advertising credibility: A study of consumer response to banner ads. Journal of Interactive Advertising, 3(1), 1224.

Chourdakis, M., Tzellos, T., Papazisis, G., Toulis, K., \& Kouvelas, D. (2010). Eating habits, health attitudes and obesity indices among medical students in northern Greece. Appetite, 55(3), 722-725. https://doi.org/10.1016/j.appet.2010.08.013

Chung, S. J., \& Hoerr, S. L. (2005). Predictors of fruit and vegetable intakes in young adults by gender. Nutrition Research, 25(5), 453-463.

Chung, S. J., Hoerr, S., Levine, R., \& Coleman, G. (2006). Processes underlying young women's decisions to eat fruits and vegetables. Journal of Human Nutrition and Dietetics, 19(4), 287-298.

Clancey, M. (1994). Winne-rof-arfs-1994 Lysaker, Richard, L. Prize for outstanding research on media - The television audience examined. Journal of Advertising Research, 34(4), U38U49.

Cohen, S. (1988). Perceived stress in a probability sample of the United States.

Davis, F. D. (1989). Perceived usefulness, perceived ease of use, and user acceptance of information technology. MIS Quarterly, 319-340.

Dehghani, M., Niaki, M. K., Ramezani, I., \& Sali, R. (2016). Evaluating the influence of YouTube advertising for attraction of young customers. Computers in Human Behavior, 59, 165172.

DeShields, O. W., Kara, A., \& Kaynak, E. (1996). Source effects in purchase decisions: The impact of physical attractiveness and accent of salesperson. International Journal of Research in Marketing, 13(1), 89-101.

Dobrian, F., Awan, A., Joseph, D., Ganjam, A., Zhan, J., Sekar, V., \& Zhang, H. (2013). Understanding the impact of video quality on user engagement. Communications of the ACM, 56(3), 91-99.

Ducoffe, R. H. (1996). Advertising value and advertising on the web-Blog@ management. Journal of Advertising Research, 36(5), 21-32.

Flanagin, A. J., Metzger, M.J., Pure, R., \& Markov, A. (2011). User-generated ratings and the evaluation of credibility and product quality in ecommerce transactions. Proceedings of the 44th International Conference on System Sciences. Hawaii: IEEE.

El Ansari, W., Stock, C., \& Mikolajczyk, R. T. (2012). Relationships between food consumption and living arrangements among university students in four European countries - A crosssectional study. Nutrition Journal, 11(28). 
El Ansari, W., Suominen, S., \& Samara, A. (2015). Eating habits and dietary intake: Is adherence to dietary guidelines associated with importance of healthy eating among undergraduate university students in Finland? Central European Journal of Public Health, 23(4), 306.

Farezza, H. R. (2017, June 7). Malaysians most obese in region. New Straits Times.

Freeman, K. S., \& Spyridakis, J. H. (2004). An examination of factors that affect the credibility of online health information. Technical Communication, 51(2), 239-263.

Fu, W. W. (2012). Selecting online videos from graphics, text, and view counts: The moderation of popularity bandwagons. Journal of Computer-Mediated Communication, 18(1), 46-61.

Fornell, C., \& Cha, J. (1993). Partial Least Squares (PLS), Unpublished working paper. Ann Arbor: University of Michigan Business School.

Gan, W. Y., Nasir, M. M., Zalilah, M. S., \& Hazizi, A. S. (2011). Disordered eating behaviors, depression, anxiety and stress among Malaysian university students. College Student Journal, 45(2), 296-310.

Ghobadi, M., Cheng, Y., Jain, A., Matthis, M. (2012, June). Trickle: Rate limiting Youtube video streaming. Presented at Proc. of 2012 USENIX Annual Technical Conference, Boston, MA, USA.

Gold, A. H., Malhotra, A., \& Segars, A. H. (2001). Knowledge management: An organizational capabilities perspective. Journal of Management Information Systems, 18(1), 185-214.

Goldsmith, R. E., Lafferty, B. A., \& Newell, S. J. (2000). The impact of corporate credibility and celebrity credibility on consumer reaction to advertisements and brands. Journal of Advertising, 29(3), 43-54.

Greer, J. D. (2003). Evaluating the credibility of online information: A test of source and advertising influence. Mass Communication and Society, 6(1), 11-28.

Gunawan, D. D., \& Huarng, K. H. (2015). Viral effects of social network and media on consumers' purchase intention. Journal of Business Research, 68(11), 2237-2241.

Hall, J. N., Moore, S., Harper, S. B., \& Lynch, J. W. (2009). Global variability in fruit and vegetable consumption. American Journal of Preventive Medicine, 36(5), 402-409.

Hair Jr., J. F., Sarstedt, M., Hopkins, L., \& Kuppelwieser, V. G. (2014). Partial least squares structural equation modeling (PLS-SEM). European Business Review.

Hair Jr., J. F., Babin, B. J., \& Krey, N. (2017). Covariance-based structural equation modeling in the Journal of Advertising: Review and recommendations. Journal of Advertising, 46(1), 163177.

Hautz, J., Füller, J., Hutter, K., \& Thürridl, C. (2014). Let users generate your video ads? The impact of video source and quality on consumers' perceptions and intended behaviors. Journal of Interactive Marketing, 28(1), 1-15.

Henseler, J., Ringle, C. M., \& Sarstedt, M. (2015). A new criterion for assessing discriminant validity in variance-based structural equation modeling. Journal of the Academy of Marketing Science, 43(1), 115-135.

Hilger, J., Loerbroks, A., \& Diehl, K. (2017). Eating behaviour of university students in Germany: Dietary intake, barriers to healthy eating and changes in eating behaviour since the time of matriculation. Appetite, 109, 100-107.

Hocevar, K. P., Flanagin, A. J., \& Metzger, M. J. (2014). Social media self-efficacy and information evaluation online. Computers in Human Behavior, 39, 254-262. 
The Influence of YouTube Advertising on the Attitude towards Fruits and Vegetables Consumption among University Students in Malaysia

Nur Shahafiqah Nadiah Jaffery, Sharifah Nurafizah Syed Annuar \& Joseph Alagiaraj Thambu Raj

Hoßfeld, T., Schatz, R., Biersack, E., \& Plissonneau, L. (2013). Internet video delivery in YouTube: From traffic measurements to quality of experience. In, Data traffic monitoring and analysis (pp. 264-301). Berlin, Heidelberg: Springer.

Huang, Y. L., Song, W. O., Schemmel, R. A., \& Hoerr, S. M. (1994). What do college students eat? Food selection and meal pattern. Nutrition Research, 14(8), 1143-1153.

Hulland, J. (1999). Use of partial least squares (PLS) in strategic management research: A review of four recent studies. Strategic Management Journal, 20(2), 195-204.

Hsu, C. L., Wang, C. F., \& Lin, J. C. C. (2011). Investigating customer adoption behaviours in mobile financial services. International Journal of Mobile Communications, 9(5), 477-494.

Jarboe, G. (2012). What's the ideal length for a YouTube marketing video? A look into video duration vs. social sharing. Tubular Insight.

Jarrett, K. (2008). Beyond broadcast yourself ${ }^{\mathrm{TM}}$ : The future of YouTube. Media International Australia, 126(1), 132-144.

Jung, M., Lin, L., \& Viswanath, K. (2015). Effect of media use on mothers' vaccination of their children in sub-Saharan Africa. Vaccine, 33(22), 2551-2557.

Kimmons, J., Gillespie, C., Seymour, J., Serdula, M., \& Blanck, H. M. (2009). Fruit and vegetable intake among adolescents and adults in the United States: Percentage meeting individualized recommendations. The Medscape Journal of Medicine, 11(1), 26.

Kline, R. B. (2011). Convergence of structural equation modeling and multilevel modeling ( $p p$. 562-589). na.

Kotler, P., \& Armstrong, G. (2010). Principles of marketing. Pearson Education.

Kontothannsis, L. (2012). Content delivery consideration for web video. Presented at Keynote at ACM Multimedia Systems 2012 (MMSys 2012), Chapel Hill, North Carolina, USA.

Lee, J. E., \& Watkins, B. (2016). YouTube vloggers' influence on consumer luxury brand perceptions and intentions. Journal of Business Research, 69(12), 5753-5760.

Lee, K. H., \& Shin, D. (2010). Consumers' responses to CSR activities: The linkage between increased awareness and purchase intention. Public Relations Review, 36(2), 193-195.

Lock, K., Pomerleau, J., Causer, L., Altmann, D. R., \& McKee, M. (2005). The global burden of disease attributable to low consumption of fruit and vegetables: Implications for the global strategy on diet. Bulletin of the World Health Organization, 83, 100-108.

Long, M. M., \& Chiagouris, L. (2006). The role of credibility in shaping attitudes toward nonprofit websites. International Journal of Nonprofit and Voluntary Sector Marketing, 11(3), 239249.

Mahima, V. A., Tiwari, R., Karthik, K., Chakraborty, S., Deb, R., \& Dhama, K. (2013). Nutraceuticals from fruits and vegetables at a glance: A review. J Bio Sci, 13, 38-47.

McKnight, D. H., \& Kacmar, C. J. (2007, August). Factors and effects of information credibility. Proceedings of the Ninth International Conference on Electronic Commerce (pp. 423-432). ACM. https://doi.org/10.1145/1282100.1282180

Mir, I. A., \& Ur Rehman, K. (2013). Factors affecting consumer attitudes and intentions toward user-generated product content on YouTube. Management \& Marketing, 8(4).

Morrison, M. A., Cheong, H. J., \& McMillan, S. J. (2013). Posting, lurking, and networking: behaviors and characteristics of consumers in the context of user-generated content. Journal of Interactive Advertising, 13(2), 97-108. 
Nielsen. (2012). State of the media: The social media report. Retrieved on April 8, 2014, from http://www.nielsen.com/content/dam/corporate/us/en/reportsdownloads/2012-

Reports/The-Social-Media-Report-2012.pdf

Norimah, J. A., Safiah, M., Jamal, K., Haslinda, S., Zuhaida, H., Rohida, S., \& Zalilah, M. S. (2008). Food consumption patterns: Findings from the Malaysian adult nutrition survey (MANS). Malaysian Journal of Nutrition, 14(1), 25-39.

Ohanian, R. (1990). Construction and validation of a scale to measure celebrity endorsers' perceived expertise, trustworthiness, and attractiveness. Journal of Advertising, 19(3), 3952.

O'Reilly, K., \& Marx, S. (2011). How young, technical consumers assess online WOM credibility. Qualitative Market Research: An International Journal, 14(4), 330-359.

Paek, H. J., Hove, T., \& Jeon, J. (2013). Social media for message testing: a multilevel approach to linking favorable viewer responses with message, producer, and viewer influence on YouTube. Health Communication, 28(3), 226-236.

Pant, S., Deshmukh, A., Murugiah, K., Kumar, G., Sachdeva, R., \& Mehta, J. L. (2012). Assessing the credibility of the "YouTube approach" to health information on acute myocardial infarction. Clinical Cardiology, 35(5), 281-285.

Pavlou, P. A., \& Fygenson, M. (2006). Understanding and predicting electronic commerce adoption: An extension of the theory of planned behavior. MIS Quarterly, 115-143.

Pikas, B., \& Sorrentino, G. (2014). The effectiveness of online advertising: Consumer's perceptions of ads on Facebook, Twitter, and YouTube. Journal of Applied Business and Economics, 16(4), 70-81.

Porto-Arias, J. J., Lorenzo, T., Lamas, A., Regal, P., Cardelle-Cobas, A., \& Cepeda, A. (2018). Food patterns and nutritional assessment in Galician university students. Journal of Physiology and Biochemistry, 74(1), 119-126.

Rashid, F. H. (2017). Malaysia most obese in region. New Straits Time.

Richards, A., Kattelmann, K. K., \& Ren, C. (2006). Motivating 18-to 24-year-olds to increase their fruit and vegetable consumption. Journal of the American Dietetic Association, 106(9), 1405-1411.

Rifon, N. J., Choi, S. M., Trimble, C. S., \& Li, H. (2004). Congruence effects in sponsorship: The mediating role of sponsor credibility and consumer attributions of sponsor motive. Journal of Advertising, 33(1), 30-42.

Sallam, M. A. A., \& Wahid, N. A. (2012). Endorser credibility effects on Yemeni male consumer's attitudes towards advertising, brand attitude and purchase intention: The mediating role of attitude toward brand. International Business Research, 5(4), 55-66.

See-To, E. W., \& Ho, K. K. (2014). Value co-creation and purchase intention in social network sites: The role of electronic Word-of-Mouth and trust - A theoretical analysis. Computers in Human Behavior, 31, 182-189.

Su, A. Y., Yang, S. J., Hwang, W. Y., \& Zhang, J. (2010). A Web 2.0-based collaborative annotation system for enhancing knowledge sharing in collaborative learning environments. Computers \& Education, 55(2), 752-766. 
Sundar, S. S. (2008). The MAIN model: A heuristic approach to understanding technology effects on credibility. In M. J. Metzger \& A. J. Flanagin (Eds.), Digital media, youth, and credibility (pp. 73-100). Cambridge, MA: The MIT Press.

Spooncer, F. 1992. Behavioural studies for marketing and business. Leckhampton, UK: Stanley Thornes Ltd.

Tang, Q., Gu, B., \& Whinston, A. (2012a). Content contribution in social media: The case of YouTube. Proceedings of the 45th Annual Hawaii International Conference on System Sciences, HICSS-45 (pp. 4476-4485). https://doi.org/10.1109/HICSS.2012.181

Tang, Q., Gu, B., \& Whinston, A. B. (2012b). Content contribution for revenue sharing and reputation in social media: A dynamic structural model. Journal of Management Information Systems, 29(2), 41-76.

Teng, S., Khong, K. W., Goh, W. W., \& Chong, A. Y. L. (2014). Examining the antecedents of persuasive eWOM messages in social media. Online Information Review, 38(6), 746-768.

Thomas, A. W., \& Weise, W. (2010). The structure of the nucleon. West Sussex, US: John Wiley \& Sons.

Viswanath, K., Ramanadhan, S., \& Kontos, E. Z. (2007). Mass media. In, Macrosocial Determinants of Population Health (pp. 275-294). NY: Springer.

Wang, Z., Walther, J. B., Pingree, S., \& Hawkins, R. P. (2008). Health information, credibility, homophily, and influence via the Internet: Web sites versus discussion groups. Health Communication, 23(4), 358-368.

Waters, R. D., \& Jones, P. M. (2011). Using video to build an organization's identity and brand: A content analysis of nonprofit organizations' YouTube videos. Journal of Nonprofit \& Public Sector Marketing, 23(3), 248-268.

Winkleby, M. A., \& Cubbin, C. (2004). Changing patterns in health behaviors and risk factors related to chronic diseases, 1990-2000. American Journal of Health Promotion, 19(1), 1927.

Woods, R. L., Satgunam, P., Bronstad, P. M., \& Peli, E. (2010, February). Statistical analysis of subjective preferences for video enhancement. In, Human Vision and Electronic Imaging XV (Vol. 7527, p. 75270E). International Society for Optics and Photonics.

Xiao, M., Wang, R., \& Chan-Olmsted, S. (2018). Factors affecting YouTube influencer marketing credibility: A heuristic-systematic model. Journal of Media Business Studies, 15(3), 188213.

Xu, Q., Schmierbach, M., Bellur, S., Ash, E., Oeldorf-Hirsch, A., \& Kegerise, A. (2012). The effects of "friend" characteristics on evaluations of an activist group in a social networking context. Mass Communication and Society, 15(3), 432-453.

Yang, M. H., Chen, J. C. H., Wu, C. H., \& Chao, H. Y. (2010). On characteristics influencing consumer's intention to use web-based self-service. Human Systems Management, 29, 41-49.

Yüksel, H. F. (2016). Factors affecting purchase intention in YouTube videos. The Journal of Knowledge Economy \& Knowledge Management, 11(2), 33-47. 